\title{
'I Have Work ... I Am Busy ... Trying to Become Who I Am': Neoliberal Girls and Recessionary Postfeminism
}

\author{
Stéphanie Genz
}

'We live in a time of deep foreboding', Henry Giroux asserts in his scathing attack on neoliberal free-market fundamentalism that has given rise to a survival-of-the-fittest world in which freedom and equality have become unaffordable luxuries for the vast majority of the population (2013, p. 257). Young people, in particular, are in danger of falling prey to neoliberalism's 'disposability machine' and being relegated to the position of 'the new precariat' - a 'zero generation' that, in Zygmunt Bauman's words, is 'cast in a condition of liminal drift, with no way of knowing whether it is transitory or permanent' (Giroux, 2013, p. 261; Bauman, 2004, p. 76). Youth no longer occupies a privileged place but is faced with an insecure and potentially bleak future, marred by the rollback of opportunities and an overarching social climate of risk, suspicion, and uncertainty. The recessionary moment is also complexly gendered, with fears abounding that we are witnessing 'the end of men' and a concomitant 'rise of women', a trend not borne out by economic reality and rising numbers of unemployed women (Rosin, 2010; see also Barrow, 2012).

S. Genz $(\bowtie)$

Department of Media Studies, Nottingham Trent University, Nottingham, UK e-mail: stephanie.genz@ntu.ac.uk

M. Nash, I. Whelehan (eds.), Reading Lena Dunham's Girls,

DOI 10.1007/978-3-319-52971-4_2 
In this chapter, I investigate the complex interplay of economic insecurity and gender in the HBO 'dramedy' Girls that follows four 20something women as they confront post-recession/post-graduation joblessness and frustrated aspirations. The series can fruitfully be read within the context of the cross-nurturing ideologies of postfeminism and neoliberalism, specifically with regard to notions of (female) entitlement, autonomy, and choice that have been increasingly problematised - and possibly invalidated - following the economic downturn. More broadly, I suggest that the larger cultural climate and ethos of neoliberal postfeminism needs to be recalibrated and reassessed in the aftermath of the boom-and-bust economic model. Certainly, if late twentieth and early twenty-first-century postfeminism was marked by optimism, entitlement and the opportunity of prosperity, such articulations have become more doubtful and less celebratory in a post-2008 recessionary environment where the neoliberal mantra of choice and self-determination is still present but becomes inflected with the experiences of precarity, risk, and the insistence on self-responsibilisation (Gilbert, 2013).

As I will discuss, the millennial girls on the show distance themselves from the caricatures of white prosperity and hyper-stylised designer femininity - variously referred to as 'top girls' (McRobbie, 2009), 'can-do girls' (Harris, 2004) and 'sexual entrepreneurs' (Gill \& Scharff, 2011 ) - popularised during the late 1990s and early 2000s and epitomised by the recession-triggering over-spenders of Sex and the City (19982004). The HBO series scrutinises and casts doubt on prevailing postfeminist/neoliberal tenets, particularly in relation to compulsory heterosexiness and competitive and acquisitive modes of subjectivity that promote the self-responsible and autonomous consumer-citizen. Yet despite the series' conscious criticality, the privileged protagonists of Girls also stubbornly adhere to a narcissistic and self-important individualism that authorises entitlement and self-absorption and insists on their right to be heard and rewarded, most notably in the shape of a memoir that narrativises the, at times purposefully objectifying and degrading, experiences of the main character Hannah. Here, as I argue, the neoliberal reflexive 'project of the self' reasserts itself (Giddens, 2008), calling upon recession-weary individuals to make sense of and profit from their own biography by updating and upgrading the self. In the case of Girls, this neoliberal logic takes on a specifically gendered, postfeminist form of self-branding that promotes (sexual) authenticity as an affective commodity in a dwindling, recessionary market (Genz, 2015), for example by acting out 
pornographic scripts and capitalising on the productive misery of the protagonists' would-be bohemian lives. If 'to truly understand and experience the "authentic" self is to brand this self" (Banet-Weiser, 2012, p. 61), then these unambitious, unemployed girls can nonetheless be seen as postfeminist enterprising subjects, claiming their neoliberal individualist privilege while fulfilling their moral imperative to realise and brand their self as 'authentic'. In this sense, in the face of its own failure, neoliberalism might be 'in crisis' but, as Stuart Hall put it, 'it keeps driving on' (Hall, 2011, p. 728).

\section{The Neoliberal Ladder and Generation Me}

Grounded in the idea of the 'free, possessive individual' and the ubiquitous and all-encompassing character of 'wealth', neoliberal ideas represent a widely circulating current that affects cultural practices of commodification, production, and consumption (Hall, 2011). Propagated prominently by the Thatcher and Reagan Regimes of the late 1970s and 1980s, neoliberal ideas, policies and strategies have incrementally gained ground globally - 'setting the pace', as Hall notes, by 're-defining the political, social and economic models and governing strategies' (2011, p. 708). Neoliberal hegemony and rationality have become embedded beyond this macro-level through cultural norms, values, and principles that have been naturalised and internalised in daily life, turning a doctrine of political economy into what McGuigan calls a 'principle of civilisation' that circumscribes the meaning of everyday reality for people and shapes their socio-cultural make-up (2014, p. 224). In this sense, neoliberalism comes to represent a 'scheme for reordering the social' as well as a 'design for refashioning the conduct of the self' (p. 228), bringing about a transformation of subjectivity that folds neoliberalism into the subject itself. In The Birth of Biopolitics (2010), Michel Foucault terms this neoliberal self homo oeconomicus, a selfgoverning and autonomous entrepreneur who invests in their own human capital in order to realise their potential without the unnecessary intervention of an oppressive government. Here, the neoliberal subject emerges as a self-sufficient and entrepreneurial agent, responsible for their own performance within the market and empowered by the expectation of self-governance. At the heart of this neoliberal transformation of the self is a distorted notion of freedom and individualism that compels neoliberal consumercitizens to make marketised choices that will allow them to get ahead in the 'game of enterprises' (Foucault, 2010, p. 173). 
Many commentators have criticised this neoliberal agenda that surrenders notions of the collective good and social responsibility to the brute ethos of self-responsibilisation (see Fisher \& Gilbert, 2013). In particular, following the post-2008 economic crisis, neoliberalism's commercial logic appears less as an individual entitlement and more a corporate obligation and institutionalised compulsion, requiring austerity-weary citizens to climb the ladder of social mobility and build what former British prime minister David Cameron referred to as an 'Aspiration Nation' (2013). ${ }^{1}$ Here, multiple strands of neoliberal politics and rhetoric converge as, on the one hand, there is an individualist insistence that there can be singular solutions to socially produced problems, followed by a meritocratic ideal that those with skills will rise to the top. Synchronously, this neoliberal ethos is also circumscribed by an inherently unequal power structure that fuels competition and undermines the common idea that we live, or should live, in a meritocratic age (see Littler, 2013). In this competitive and linear model, more people are in danger of being left behind, unable to maintain a secure foothold on the neoliberal ladder that penalises failure and rewards acquisitive and enterprising self-interest. Henry Giroux is perhaps most vehement here in his description of the neoliberal world as a Darwinian shark tank that celebrates the survival of the fittest and ruthlessly imposes a practice of disposability in which more groups are relegated to 'inhabiting zones of abandonment marked by deep inequalities in power, wealth and income' (Giroux, 2011).

Young people in particular are caught in the neoliberal trap, often struggling to develop the selfish resourcefulness demanded of them to counteract the threat of downward mobility. As Giroux warns, 'nothing has prepared this generation for the inhospitable and savage new world of commodification, privatization, joblessness, frustrated hopes, surveillance and stillborn projects' (2011). Here, young people are viewed as potentially dispensable, holding on to the meritocratic promise that talent and ambition can be converted into economic capital, while simultaneously facing an insecure future of increasing debt and itinerant internshipping. Set in the market-driven metropolis of New York City, Girls highlights the uncertain situation of a young middle-class generation setting out to succeed in a highly competitive, (post-)recession workplace where personal initiative and enterprising creativity are at a premium. The series centres on the work-related and personal mishaps of four privileged university-educated white girls who are struggling to get by in contemporary upscale Brooklyn, well aware that they are 'all slaves to this place that 
doesn't even ... want us' (Season 1, Episode 6, 'The return'). None has managed to secure a full-time, viable job in the 'real' world and instead they depend on the financial support of their (grand)parents in order to fulfil their supposedly abundant potential. 'I am so close to the life that I want, the life that you want for me', Hannah tells her parents in the pilot episode as she tries to convince them to keep subsidising her career as an aspiring yet unpaid writer. Drifting from one zero-hour contract to the next, she embraces a life of 'justified aimlessness' (Fuller \& Driscoll, 2015 , p. 257), undeterred by her persistent failure to claim her place in a world that, given her privileged background and education, should rightfully be hers.

In Zygmunt Bauman's words, Hannah is emblematic of a modern 'disembedded' individual, 'constantly on the run and promising no rest and no satisfaction of "arriving", no comfort of reaching the destination where one can disarm, relax and stop worrying' (2001, p. 125). In this context, identification is a never-ending, always incomplete and precarious activity that transforms 'identity' from a 'given' into a 'task' (pp. 124, 129). As Bauman explains, '[n] eeding to become what one is is the feature of modern living' as 'the quandary tormenting men and women [...] is not so much how to obtain the identities of their choice $[\ldots]$ but which identity to choose, and how best to keep alert and vigilant so that another choice can be made in case the previously chosen identity is withdrawn from the market or stripped of its seductive powers' (pp. 124, 126). The eponymous girls appear to be stuck in this endless state of becoming, 'jitter[ing] [their] way through [their] twenties' and struggling to 'turn this potential energy into connected energy' (Season 1, Episode 6, 'The return'; Season 2, Episode 8, 'It's back'). As Marnie tells her ex-boyfriend Charlie after losing her job: 'I don't even know what I want. Sometimes I wish someone would tell me this is how you should spend your days, this is how the rest of your life should look' (Season 2, Episode 4, 'It's a shame about Ray'). This is reinforced by the main character Hannah's insistence that 'I am busy trying to become who I am' (Season 1, Episode 1, 'Pilot'), followed by her anxious plea, 'I'm more scared than most people are when they say they're scared' (Season 1, Episode 10, 'She did').

Here, we can also interrogate the interplay of economic uncertainty and gender that casts doubt on the discourses of self-regulating entrepreneurship and choice that were the hallmark of 1990s celebratory neoliberalism/postfeminism and that are embodied in the image of the 'empowered, assertive, pleasure-seeking, "have-it-all" woman of sexual 
and financial agency' (Chen, 2013, p. 441). For example, Lazar's suggestion that 'the postfeminist subject $[\ldots]$ is entitled to be pampered and pleasured' needs to be problematised in the context of a post-recession environment that no longer guarantees (economic) success and reward to even most hard-working individuals $(2009$, p. 372$)$. Despite their privileged upbringing, Hannah and her friends are far removed from what McRobbie calls 'top girls' characterised by 'capacity, success, attainment, enjoyment, entitlement, social mobility and participation' (2009, p. 57). As the series' creator Lena Dunham has repeatedly stressed, despite the obvious narrative similarities, Girls is not an updated version of Sex and the City, undermining the link between individual empowerment and gendered consumer practices, for example through the display of a hyper-sexualised and commodified body and the performance of designer femininity. These 'can't-do' girls do not consume voraciously or engage in endless shopping sprees funded by their glamorous yet curiously undemanding jobs, nor is their 'failing' represented as a virtue (McRobbie, 2009), as might have been the case with other postfeminist heroines like Bridget Jones, typified by professional ineptness and persistent blundering. Under-achievement and incompetence are no longer endearing signs of female identification and imperfection, but equivalent to economic suicide as countless, qualified professionals compete in an ever shrinking job market. In this sense, the prospect of prosperity and entrepreneurship that might have been viewed with optimism in the pre-recession decades comes to be seen as an institutionalised burden that masks the roll-back of opportunities under the rhetorical guise of necessity and self-responsibility.

At the same time, other central neoliberal strands reassert themselves, as one cannot help reading the girls' youthful restlessness and existential anxiety refracted through the lens of a narcissistic and selfish kind of individualism that legitimises an obsessive investment in self-interest. In Shoshanna's words, Hannah is a 'fucking narcissist ... who thinks her own life is ... fascinating' (Season 3, Episode 7, 'Beach house') - despite her proclaimed self-loathing and criticality. ${ }^{2}$ Instead of forging affective female bonds that were a key marker of postfeminist texts like Sex and the City, these recessionary neoliberal girls are in it mainly for themselves, trying to outdo one another in their search for the most meaningful (i.e. valuable) identity. Hannah clearly exhibits what Halpern calls a 'Prima Donna mindset' (2007, p. 197), constantly looking for the recognition and admiration she thinks she deserves. In this sense, the 'zero 
jobs/zero future' predicament of the new precariat (Giroux, 2013, p. 261) morphs into the angst-ridden selfishness of what psychologist Jean Twenge (2006) describes as 'Gen Me', the entitled generation of millennials whose high self-esteem and self-worship have been encouraged since childhood, and who end up disengaged, anxious, and self-absorbed adults. Hannah and her friends stubbornly cling to a neoliberal/postfeminist rhetoric of entitlement, banking on the consumerist mantra that they are clearly 'worth it' and the meritocratic promise that their 'talent' will eventually propel them to the top of the ladder. This allows them to cultivate a lack of ambition and hedonistic laziness that are at odds with an undeniably harsh economic climate - as Jessa neatly summarises her selfimposed unemployability: 'The weirdest part of having a job is ... you have to be there every day, even on the days you don't feel like it' (Season 1, Episode 4, 'Hannah's diary'); while Hannah flatly rejects the idea of working at McDonalds because 'I went to college' (Season 1, Episode 1, 'Pilot'). All four characters continue to make bad career decisions and adopt inappropriate work conduct, from Hannah calling a potential employer a rapist (Season 1, Episode 2, 'Vagina panic') and giving up her place at graduate school (Season 4, Episode 4, 'Cubbies') to Shoshanna arrogantly dismissing a successful job interview as a 'trial ... to hone my skills' (Season 4, Episode 3, 'Female author'). As Bell observes, such youthful and directionless indecision is a 'luxury afforded to those who have choices - who are socially mobile' (2013, p. 364). Despite their much touted 'potential', these workshy and entitled girls lack the skills and determination needed in an unstable recessionary labour market - as Hannah's short-term employers tell her, she doesn't 'know how to do anything' (Season 1, Episode 5, 'Hard being easy') and is not 'hungry enough [to] figure it out' (Season 1, Episode 1, 'Pilot').

The pitfalls of the neoliberal contract are clearly apparent here as Hannah and her friends hold on to a hyper-individualistic conception of selfhood as the key to unlock human capital, despite the economic fact that their respective self-commodities might not be as marketable and saleable as they had been led to believe by a meritocratic, neoliberal logic. While Hannah might not be 'meant for a job in the traditional sense' (Season 1, Episode 5, 'Hard being easy'), she is nonetheless engaged in a continuous process of self-work, mining meaning (i.e. value) from her unproductive artist's life and theatrically staging a series of (sexual) fantasies that can be exploited and narrativised for her memoir. Everything that happens to Hannah - or, is choreographed to happen to 
her - becomes material for her book: as she tells her parents, she cannot write more essays as she has to 'live them first' (Season 1, Episode 1, 'Pilot'). Yet, her sheltered, middle-class life does not always yield enough excitement and is constantly on the verge of wilting into egocentric and dull introspection. As one of her short-lived boyfriends tells Hannah after reading her story, ' $[\mathrm{n}]$ othing was happening. ... It felt like just waiting in line and all the nonsense that goes through your brain when you are trying to kill time' (Season 2, Episode 2, 'I get ideas'). Battling her own mediocrity, Hannah's claim that 'I may be the voice of my generation, or at least a voice of a generation' (Season 1, Episode 1, 'Pilot') becomes a compelling and ironic reminder that 'killing time' may indeed be a shared social condition affecting in particular young people looking for a sense of self and purpose. As Zygmunt Bauman explains, '[i]f you cannot - or don't believe you can - do what truly matters, you turn to things which matter less or perhaps not at all, but which you can do or believe you can; and by turning your attention and energy to such things, you may even make them matter, for a time at least' (2001, p. 128). In this sense, Hannah busies herself perfecting her own biography and posture of millennial malaise, immersing herself in a number of self-directed and orchestrated experiences that she hopes can be capitalised on.

\section{Self-branding and the Gendering of Authenticity}

Hannah's biographical production can thus be read as part of neoliberalism's reflexive 'project of the self' that encourages individuals to become the authors of their own life scripts and constantly work to update/ upgrade the self (Giddens, 2008). As she confidently declares, 'I made a promise ... that I was gonna take in experiences, all of them so I could tell the people about them' (Season 2, Episode 5, 'One man's trash'). In search of a good story, Hannah is willing to act out exploitative scenarios and scripts of sexual surrender, including propositioning her employer for sex after he harassed her (Season 1, Episode 5, 'Hard being easy'), enacting her boyfriend's rape fantasies (Season 1, Episode 2, 'Vagina panic') and taking drugs to advance her career - as her female boss tells her, 'do a whole bunch of coke, and just write about it' (Season 2, Episode 3 , 'Bad friend'). At the same time, Hannah's narcissistic narrativising of her self has cultivated a stance of callous disconnection - or 'sociopathic detachment' according to her co-worker Ray (Season 3, Episode 4, 'Dead inside') - that manifests itself in an egotistic lack of interest in others: 'I feel 
nothing', she admits after her editor dies (Season 3, Episode 4, 'Dead inside'). Refracting life's offerings through a narrative lens, the millennial girls have become performers in their own screenplay, evaluating events and people for their inherent value and capital to enhance the commodity of the self. This entails constructing a "social relationship" with oneself, one of innovation, production, and consumption' (Banet-Weiser, 2012, p. 73). As such, Hannah's memoir can be seen as her main asset in the contemporary 'experience economy', where consumers no longer merely consume goods and services but they are looking for memorable events that engage them in a personal way (Pine \& Gilmore, 1999). Her insistent question 'Who am I?' thus becomes translated into 'How do I sell myself?' as her self-work turns into a branding exercise aiming to produce a saleable identity that can be traded and consumed by others.

Here, we need to take into account the 'affective relational' quality - or, experience - of brands that is maintained through personal narratives; in Banet-Weiser's words, 'brands are actually a story told to the consumer' and 'the setting around which individuals weave their own stories' (2012, p. 4). More than just an economic capitalist strategy, 'the process of branding', she argues, 'impacts the way we understand who we are, how we organize ourselves in the world, what stories we tell ourselves about ourselves' (p. 5). In the context of brand culture, individuals craft their own identities as marketable products capable of generating demand and attracting customers. In this instance, identity might be referred to more accurately as a self-brand that 'either consciously positions itself, or is positioned by its context and use, as a site for the extraction of value' (Hearn, 2008, pp. 164-5). In other words, identity becomes part of a business context and market rationale that valorise both the subject and the merchandising of it, highlighting the blurring of the individual and commodity aspects of selfhood.

In Girls, the characters' continuous becoming 'who they truly are' or 'who they are meant to be' can only be grasped and realised through a selfbranding framework that is set up by commercial culture. Hannah's publishers summarily reduce her painstakingly crafted memoir to a sales pitch: 'What's your brand?', 'Who are we selling?' (Season 3, Episode 5, 'Only child'). Hannah's brand chiefly revolves around the conscious construction and narrativisation of herself as a struggling artist and sexual libertine, offset by the creeping awareness that she might not live up to this fictional type. Nor does Hannah prove fully capable of capitalising on her identity project and straddling the slippery line between self-work 
and self-promotion - as her gauche, less market-savvy answer reveals, 'My brand is Tombstone Pizza' (Season 3, Episode 5, 'Only child'). Her self-production takes on specifically gendered dimensions as she weaves stories of female (in)dependence and (dis)empowerment as part of her narrative of the self. The unique selling point of her self-brand is its perceived authenticity and honesty, as Hannah 'put[s] [herself] out there' (Season 1, Episode 8, 'Weirdos need girlfriends too), 'trying to take in all these experiences for everybody, letting anyone say anything to me' (Season 2, Episode 5, 'One man's trash'). This is reinforced by other characters throughout the series - from Ray's initial attraction to Shoshanna because she is 'so raw and open' (Season 1, Episode 10, 'She did') to Elijah's insistence 'I am my authentic self' upon outing himself as gay (Season 1, Episode 3, 'All adventurous women do') and Adam's justification for quitting his acting job, '[y]our integrity is all that matters' (Season 1, Episode 8, 'Weirdos need girlfriends too'). In this branded environment, authenticity needs to be recognised as a 'new consumer sensibility' (Pine \& Gilmore, 1999) - endowing products with a kind of 'commercial story telling' that generates emotional content and desire (Lewis \& Bridger, 2000, p. 39). As Boyle (2003, p. 26) notes, 'authenticity is the benchmark against which all brands are now judged'.

In Hannah's case, the authentic capital is also materialised in corporeal form as she frequently flaunts her non-conforming naked body, from taking baths with her female friends to engaging in non-stylised, explicit and degrading sexual encounters. In effect, her body takes centre stage in her production of authenticity, exposing its non-slender and non-athletic flesh in a graphic, uninhibited, and at times comic fashion. She directly relates her non-normative body to her refusal to engage in self-disciplining and self-monitoring regimes of diet and exercise - as she notes, 'I have not tried a lot to lose weight. ... I have some other concerns in my life' (Season 1, Episode 3, 'All adventurous women do'). Exceeding the narrow boundaries of normative femininity, Hannah's body visibly escapes the tyranny of slenderness and, in this sense, can be read as a symptom of her self-assumed authenticity and criticality. In particular, what is being replayed here is a well-rehearsed (feminist) critique of white, heterosexual, middleclass norms of (feminine) beauty that result in a mainstreaming and normalisation of female bodies - the type of conventionally attractive bodies that are still present and visible in Girls in the shape of the allAmerican beauty Marnie, and Jessa who has 'the face of Brigitte Bardot 
and the ass of Rhianna' (Season 1, Episode 4, 'Hannah's diary') (see Bartky, 1997). Parading its own imperfection, Hannah's body is marked as 'authentic' in comparison and acquires a sense of 'realness' that can purposefully be exploited and narrativised in the service of her own self-brand. Moreover, while her corporeal authenticity is linked to sexual exposure, her body is not eroticised in a pornographic way, nor does it exhibit a kind of obligatory heterosexiness that is a key characteristic of the postfeminist 'sexual entrepreneur' who is always 'up for it' (Gill \& Scharff, 2011). In Girls, sex is not stylish and it is not always a source of physical pleasure and individual fulfilment - on the contrary, it is often ugly, awkward and discomforting, both for the characters themselves and for the audience to watch.

In this respect, the series' staging of sexual and bodily authenticity is clearly in line with the brand requirements of $\mathrm{HBO}$, dedicated to creating 'quality television' and pushing boundaries, patently exemplified by the network's most popular drama, Game of Thrones (2011-), replete with gore, graphic nudity and violence (see Genz, 2016). In its pursuit of authentic female experiences, Girls is similarly devoted to a kind of edgy controversy that appeals to our critical capacities by foregrounding the self-aware artistry with which the female characters approach their life projects. The series adopts a stance of implicit criticality and self-reflexivity, often anticipating viewers' frustrations with the selfish individualism adopted by the main characters - audible, for example, in Ray's rejection of Hannah's writing as trivial intimacy compared to 'real' subjects, such as 'racial profiling', 'cultural criticism', and 'death' (Season 1, Episode 9, 'Leave me alone'). Yet, while we are clearly interpellated as critical consumers, we are also confronted with the limited scope and potency of that very critique. In this sense, the girls' bohemian posturing and their production of a 'unique' and 'authentic' identity might amount to no more than a 'cool-capitalist' stance that incorporates signs and symbols of disaffection to popular and extremely profitable effect (McGuigan, 2009). As Hannah repeatedly discovers, her project of the self is fraught with tensions because, in the end, it needs to be legible and marketable within the terms set up by a recessionary brand culture that no longer rewards the immaterial labour that individuals invest to create their 'authentic self'. Hannah's self-brand is thus in danger of remaining on the shelf as others refuse to buy into her authenticity - as Jessa puts it, 'this book does not matter. It's not going to matter to the people who read it or 
to you' (Season 2, Episode 6, 'Boys'). Ultimately, the girls might have no option but to forgo their narcissistic authenticity in favour of a more productive and lucrative brand of individualism and critical compliance, symptomatic of a more intensified neoliberalism.

\section{Notes}

1. As Cameron put it at the Conservative Party Spring Conference in March 2013: 'We are building an Aspiration Nation. A country where it's not who you know, or where you're from; but who you are and where you're determined to go. My dream for Britain is that opportunity is not an accident of birth, but a birthright' (Cameron, 2013).

2. As Banet-Weiser explains, 'at its core, narcissism is about total self-importance, an importance that authorizes entitlement, self-absorption, lack of personal accountability, and a whole host of other undesirable qualities. $[\ldots][\mathrm{T}]$ he most substantial manifestation of this kind of narcissism is the expectation and assumption of an audience, implying not simply the right to speak but the right to be heard' (2012, p. 87).

\section{REFERENCES}

Banet-Weiser, S. (2012). Authentic TM: The politics of ambivalence in a brand culture. New York: New York University Press.

Barrow, B. (2012, 16 February). Women workers bearing the brunt of rising job losses as twice as many men keep jobs. Daily Mail. Retrieved from http:// www.dailymail.co.uk/news/article-2 $101796 /$ Women-workers-bearingbrunt-rising-job-losses-twice-men-jobs.html.

Bartky, S.L. (1997). Femininity and domination: Studies in the phenomenology of oppression London: Routledge.

Bauman, Z. (2001). Identity in the globalising world. Social Anthropology, 9(2), $121-129$.

Bauman, Z. (2004). Wasted lives. London: Polity.

Bell, K. (2013). Obvie, we're the ladies! Postfeminism, privilege, and HBO's newest Girls. Feminist Media Studies, 13(2), 363-366.

Boyle, D. (2003). Authenticity: Brands, fakes, spin and the lust for real life. London: Harper Perennial.

Cameron, D. (2013). Speech to the National Conservative Convention. Retrieved from http://www.ukpol.co.uk/2015/11/20/david-cameron-2013-speechto-the-national-conservative-convention/.

Chen, E. (2013). Neoliberalism and popular women's culture: Rethinking choice, freedom and agency. European Journal of Cultural Studies, 16(4), 440-452. 
Fisher, M., \& Gilbert, J. (2013). Capitalist realism and neoliberal hegemony: A dialogue. New Formations: A Journal of Culture, Theory \& Politics, 80-81, 89-101.

Foucault, M. (2010). The birth of biopolitics: Lectures at the College de France. Basingstoke: Palgrave.

Fuller, S., \& Driscoll, C. (2015). HBO's Girls: Gender, generation, and quality television. Continuum: Journal of Media e Cultural Studies, 29(2), 253-262.

Genz, S. (2015). My job is me: Postfeminist celebrity culture and the gendering of authenticity. Feminist Media Studies, 14(5), 545-561.

Genz, S. (2016). I'm not going to fight them, I'm going to fuck them: Sexist liberalism and gender (a)politics in Game of Thrones. In R. Schubart \& A. Gjelsvik (Eds.), Women of ice and fire: Gender, Game of Thrones and multiple media engagements (pp. 243-266). New York: Bloomsbury.

Giddens, A. (2008 [1991]). Modernity and self-Identity: Self and society in the late modern age. Cambridge: Polity.

Gilbert, J. (2013). What kind of thing is 'neoliberalism'? New Formations: A Journal of Culture, Theory \& Politics, 80-81, 7-22.

Gill, R., \& Scharff, C. (Eds.) (2011). New femininities: Post-feminism, neoliberalism and subjectivity. Basingstoke: Palgrave Macmillan.

Giroux, H. (2011). Neoliberalism and the machinery of disposability. Retrieved from http://www.truth-out.org/opinion/item/22958-neoliberalism-andthe-machinery-of-disposability.

Giroux, H. (2013). The disimagination machine and the pathologies of power. Symploke, 21(1-2), 257-269.

Hall, S. (2011). The neo-liberal revolution. Cultural Studies, 25(6), 705-728.

Halpern, J. (2007). Fame junkies: The hidden truths behind America's favorite addiction. Boston: Houghton Mifflin.

Harris, A. (2004). Future girl: Young women in the twenty-first century. London: Routledge.

Hearn, A. (2008). Meat, mask, burden: Probing the contours of the branded self. Journal of Consumer Culture, 8(2), 163-183.

Lazar, M. (2009). Entitled to consume: Postfeminist femininity and a culture of post-critique. Discourse and Communication, 3(4), 371-400.

Lewis, D., \& Bridger, D. (2000). The soul of the new consumer. London: Nicholas Brealey.

Littler, J. (2013). Meritocracy as plutocracy: The marketising of 'equality' under neoliberalism. New Formations: A Journal of Culture, Theory o Politics, 80-81, $52-72$.

McGuigan, J. (2009). Cool capitalism. London: Pluto.

McGuigan, J. (2014). The neoliberal self. Culture Unbound, 6, 223-240.

McRobbie, A. (2009). The aftermath of feminism: Gender, culture and social change. London: Sage. 
Pine, J. B., \& Gilmore, J.H. (1999). The experience economy: Work is theatre \& every business a stage. Boston: Harvard Business School Press.

Rosin, H. (2010, July/August). The end of men. The Atlantic. Retrieved from http://www.theatlantic.com/magazine/archive/2010/07/the-end-of-men/ $308135 /$.

Twenge, J. (2006). Generation me: Why today's young Americans are more confident, assertive, entitled - and more miserable than ever before. New York: Free Press.

Stéphanie Genz is Senior Lecturer in Media Studies at Nottingham Trent University, UK. She specialises in contemporary gender and cultural theory. Her book publications include Postfeminist Gothic: Critical Interventions in Contemporary Culture, Postfeminism: Cultural Texts and Theories and Postfemininities in Popular Culture. Stéphanie's current work centres on sexist liberalism/liberal sexism in post-recessionary culture that belies assumptions of gender equality and sexual freedom. 